\title{
Using Some Available Palm Residues in New Valley as Alternative Bedding Materials for Raising Broilers
}

\author{
Farghly M. F., A. ${ }^{1}$, El-Kelawy, M. I. ${ }^{2}$, Kassab, A. Y. ${ }^{2}$ and Hashem, A. M. ${ }^{2}$
1. Dept. Of Poultry Production, Fac. Of Agric., Univ. Of Assiut (71516), Egypt.
2. Dept. Of Poultry Production, Fac. Of Agric., Univ. Of New Valley, Egypt
}

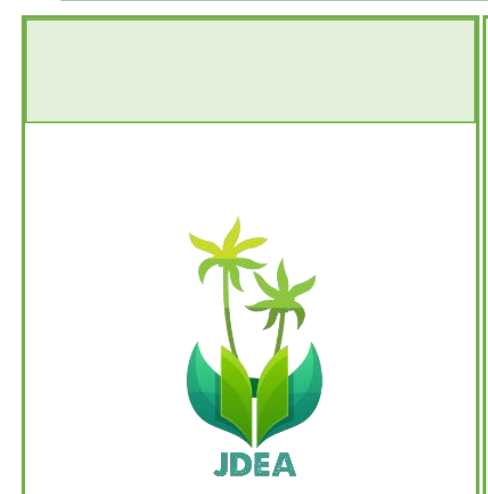

$\underline{\text { Abstract }}$

This study was conducted to evaluate the effect of some available plant residues as alternative litter materials in New Valley on growth performance, carcass traits, health status and economic efficiency of broiler. A total number of 180 one day old chicks of Cobb broiler were used. The study included six groups of treatments, with three replicates for each treatment (10 chicks per each); (wheat straw, wood sawdust, rice hulls, corn stalks chips, chopped palm fiber and palm spines chips litters). Results of growth performance (body weight, body weight gain, feed consumption and feed conversion) at market age, showed significant differences $(\mathrm{P} \leq 0.05)$ among studied litter types. Broiler reared on wheat straw, corn stalks chips and palm spines chips litters had significant superiority of body weight and gain over the broiler reared on wood sawdust, rice hulls and chopped palm fiber. Also, feed conversion of broiler reared on wheat straw, wood sawdust, corn stalks chips and palm spines chips litters had significant superiority values over the broiler reared on rice hulls and chopped palm fiber litters. No significant differences were found in dressed carcass, while, the lowest abdominal fat is observed for broilers raised on wood sawdust, corn stalks chips and

\section{Article info.}

Received on:20-1-2021

Accepted on: 16-2-2021

Published on: 3-2021

Open Access chopped palm fiber litters. Broilers raised on wheat straw and wood sawdust had a significantly $(\mathrm{P} \leq 0.05)$ higher bursa percentage than those of birds raised on rice hulls and chopped palm fiber litters. The keel bone length for birds raised on wood sawdust, corn stalks chips and palm spines chips litters had significantly $(\mathrm{P} \leq 0.05)$ higher value as compared to those raised on chopped palm fiber litter. The lowest leg problems score is observed for broilers raised on corn stalks chips litter in comparison with those raised on rice hulls and chopped palm fiber litters. Depends on the economic efficiency and availability palm spines chips can be used as litter material instead of wood sawdust and wheat straw. In conclusion, corn stalks chips and palm spines chips can potentially be used as alternative litter materials for managing broilers in New Valley.

Keywords: Litter, growth performance, carcass traits, health status, broiler

Journal of Desert and Environmental Agriculture, 2021. 


\section{Introduction}

It is well known that poultry industry is one of the most dynamic of world's agribusiness trade. Furthermore, broiler production is generally acceptable to people all over the world and provides an excellent source of protein. Moreover, many of researchers showed that broiler growth is significantly influenced by environmental and managerial conditions. In broiler management, litter type has important influence broiler on performance, where good litter conditions lead to obtain optimum results of final productive traits and profits (Farghly $\boldsymbol{e t}$ al., 2020).

Litter is a mixture of excreta, spilled feed, spontaneously fallen feathers and farm bedding material (Seidavi et al., 2015). Good litter should be characterised by light weight, medium-sized, good absorption property, fast drought, soft and easy to compress, low heat conductivity, low price and possess high efficiency of moisture absorption with a reasonable drying time (Munir et al., (2019; Farghly et al., 2021). Poor litter quality is considered a welfare problem in modern poultry production (Bilgili et al., 2009). Litter serves several functions that include thermal insulation, moisture absorption and protective barrier from the ground. Moreover, it permits birds natural scratching behavior (Škrbić et al., 2012). Litter quality may play an important role in leg and skin health conditions, encouraging normal behaviours and broiler welfare (Farghly 2017; Amer, 2020).

In Egypt, most commonly used type of litter materials in broiler farms are wheat straw and wood sawdust. As a result of the limited availability, low supplies and expense of wheat straw and wood sawdust, many broiler producers are searching for alternative bedding materials (Kuleile $\boldsymbol{e t}$ al., 2019; Monckton, et al., 2020). In New Valley, the use of other crop and palm residues has shown good potential as alternative bedding materials especially chopped palm fiber and palm spines chips litters for managing broilers due to their availability with cheap prices. There is little information on growth performance of broiler reared on chopped palm fiber and palm spines chips as litter materials. For that reason, the objective of this study was to evaluate the effect of some palm residues as litter materials on the performance of broilers under the prevailing environmental conditions in New Valley.

\section{Materials and Methods}

The experiment was carried out at the broiler farm (د/1/092/108) in Nasser city, El-Kharga, New Valley governorate, Egypt. The experiment was planned to evaluate the effect of the some available plant residues as alternative litter materials in New Valley on the growth performance, carcass traits, health status and economic efficiency of broiler. A total number of 180 one day old chicks of Cobb broiler were used. The study included six groups of treatments, with three replicates for each treatment (10 chicks per each); (wheat straw, wood sawdust, rice hulls, corn stalks chips, chopped palm fiber and palm spines chips litters). Each replicate was kept in a partition of 1 meter square provided with deep litter $(8-10 \mathrm{~cm})$. The chicks were maintained under continuous lighting and vaccinated against New castle disease. The chicks were maintained under continuous lighting. The feed and fresh water were provided ad libtum and management condition was similar for all treatments throughout the experimental period. The birds fed commercial diets: starter diet from 0-2 wks of age (23\% crude protein and $3000 \mathrm{Kcal}$. ME $/ \mathrm{kg}$ of diet); grower diet from 3-4 wks of age ( $21 \%$ crude protein and $3100 \mathrm{Kcal}$. ME / kg of diet); finisher diet from 5-6 wks of age (19\% crude protein and $3200 \mathrm{Kcal}$. ME / $\mathrm{kg}$ of diet). The chicks were reared under 32$33^{\circ} \mathrm{C}$ temperature at one-day of age and then gradually reduced to reach $23^{\circ} \mathrm{C}$ at the fourth week of age and thereafter.

The average of body weights (BW) at $0,1,2,3,4,5$ and 6 weeks of age were recorded and body weight gain (BWG) was calculated weekly. The weekly averages of feed consumption (FC) and 
feed conversion values ( $\mathrm{g}$ feed/g gain; FCR) were calculated weekly from 0 to 6 wks of age. At 6 weeks of age, 2 broilers/ pen for a total of 6 chickens/ treatment were chosen randomly and fasted for 8 hours before slaughtering. The edible organs (spleen, bursa, thymus glands, empty gizzard and spleen) as well as the abdominal fat were removed, weighed and calculated as percentages of carcass weight. The dressing percentage was calculated by dividing the carcass and giblets weights by the pre-slaughter live body weight of birds. At 6 weeks of age, birds per replicate were examined and scored (on a scale of 1 to 5) for leg problems, breast blisters and body measurements. The economical efficiency based on the average costs of feed consumed and litter quantities used as well as the average income/bird were calculated. The net revenue per bird was estimated as the difference between the total sale price (LE), and the costs (LE) of feeds consumed and litter used, according to the prevailing prices in the local Egyptian market during the experimental period during the experiment.

\section{Statistical Analysis}

Data collected were subjected to analysis of variance by applying the General Linear Models Procedure of SAS software (SAS Institute, version 9.2, 2009). Duncan (1955) was used to detect differences among means of different groups. The percentages of carcass and organs were transformed to Arcsin values then re-transformed to the original values after analysis. The following model was adopted for analysis of variance:

$$
\mathrm{Xij}=\mu+\alpha \mathrm{i}+\beta \mathrm{j}+\epsilon_{\mathrm{ij}}
$$

Where: $\mathrm{Xij}=$ an observation, $\mu=$ overall mean, $\alpha \mathrm{i}=$ replicates effect, $\beta \mathrm{j}=$ bedding type effect and $\epsilon_{i j}=$ experimental random error.

\section{Results and Discussion}

\subsection{Body weight (BW) and body weight gain (BWG):}

Data of the BW and BWG are presented in Tables (1 and 2). There are significant differences $(\mathrm{P} \leq 0.05)$ in $\mathrm{BW}$ of birds as affected by litter type at 6 weeks of age. The BW for birds raised on wheat straw, corn stalks chips and palm spines chips litters had significantly $(\mathrm{P} \leq 0.05)$ higher BW at 6 the week of age as compared to those grown on rice hulls and chopped palm fiber litters, while wood sawdust litter group had intermediate value. The overall means of BWG, showed significant increase for birds raised on wheat straw, wood sawdust, corn stalks chips and palm spines chips litters compared with those raised on rice hulls and chopped palm fiber litters. The reduction in growth for birds reared on rice hulls or chopped palm fiber litters may be due to increased leg disorders and feet lesions that make birds unable to walk and reach feeders and waterers. It has been indicated that broilers with severe foot lesions show slower live weight (Amer, 2020).

The present results are in partial agreement with those of Atencio et al., (2010), Yildiz et al. (2014), Shepherd et al. (2017), Lonkar et al. (2018) and Monckton, et al., (2020) who found that wood sawdust is associated with significant heavier BWG at 5-6 weeks of age as compared with those raised on straw based litters. In contrast, Grimes et al., (2006), Avila et al., (2008), Davis et al., (2010), Farghly (2012) and Farghly et al. (2015\& 2020) reported insignificant differences in BW of broilers, quails and turkeys raised on different alternative litter materials. Moreover, Kuleile et al., (2019) found that litter material treatment had no significant influence on body weight gain.

\subsection{Feed consumption (FC) and feed conversion ratio $(\mathrm{FCR})$ :}

The results of Table 3 showed no significant differences in FC among the experimental groups; however the mean of FC birds raised on wheat straw and chopped palm fiber litters during from 5 to 6 weeks of age were significantly $(\mathrm{P} \leq 0.05)$ increased than that of birds raised on wood sawdust, corn stalks chips and palm spines chips litters, while rice hulls litter group 
had intermediate value. During the periods from 5 to 6 weeks of age, the averages of FCR for birds raised on wheat straw, wood sawdust, corn stalks chips and palm spines chips litters had significantly $(\mathrm{P} \leq 0.05)$ better values than that of birds raised on rice hulls and chopped palm fiber litters. The overall means of FCR for birds raised on wheat straw, wood sawdust, corn stalks chips and palm spines chips litters significantly $(\mathrm{P} \leq 0.05)$ improved than that of birds raised on rice hulls litter, while birds raised on chopped palm fiber litter had intermediate value (Table 4).

The obtained results of the effect of litter types on the FC are in agreement with the findings of Toledo et al., (2019) who, showed insignificant differences in FC of broilers, compared to wood sawdust. Subgroup meta-analysis revealed that straw, when used as an alternative litter material to wood sawdust, may be responsible for worse feed conversion. Also, Nawar et al., (2019) reported that there were no significance differences in feed consumption. Similar results were obtained by Mohammed et al., (2019) and Balaban and Rathert (2020). Munir et al., (2019) and Farghly et al. (2020) found that the birds show improvement in different performance parameters, for example, up to 5-7\% improvement in FCR. Similarly, Amer et al., (2015) found that significant differences $(\mathrm{P} \leq 0.05)$ among broilers of litter types in FC and FCR. The findings achieved by Ramadan and Khloya (2017) indicated that litter type had no obvious effect over feed conversion ratio. Contrary to our results, Dhaliwal $\boldsymbol{e t}$ al., (2018) reported that differences in FC and FCR of wheat straw, rice husk, mustard stalk groups were significantly higher that for sand.

\subsection{Carcass characteristics:}

Date presented in Table (5) showed no significant differences were found in dressed carcass, giblets and thymus percentages which could be owed to the type of litter. The lowest abdominal fat \% is observed for broilers raised on wood sawdust, corn stalks chips and chopped palm fiber litters in comparison with those raised on wheat straw litter, while birds raised on rice hulls and palm spines chips litters had intermediate values. Concerning, the immune organs, birds raised on wheat straw and wood sawdust litters had a significantly $(\mathrm{P} \leq 0.05)$ increase in bursa percentage than those of birds raised on rice hulls and chopped palm fiber litters. Broilers raised on wood sawdust and chopped palm fiber litters significantly $(\mathrm{P} \leq 0.05)$ increased in spleen than those of birds raised on rice hulls litter.

The results of the present work are in agreement with findings of Bilgili $\boldsymbol{e t} \boldsymbol{a l}$. (2009), Huang et al. (2009), Atencio et al. (2010), Davis et al. (2010), Farghly (2012), Farghly et al., (2015) and Farghly et al. (2018\& 2020). On the other hand, Demirulus (2006) found that carcass weight and carcass yield of a pine sawdust group were significantly higher than those reared on straw and mixed litter. Toghyani et al. (2010) indicated that gizzard percentages of broiler were not affected by litter type. Litter moisture content may influence carcass yield and may cause carcass lesions (Traldi et al., 2007).

\subsection{Body measurements and health status:}

The results presented in Table (6), showed that the keel bone length for birds raised on wood sawdust, corn stalks chips and palm spines chips litters had significantly $(\mathrm{P} \leq 0.05)$ higher keel length as compared to those for chopped palm fiber litter, while birds raised on wheat straw and rice hulls litters groups had intermediate value. However, the lowest leg problems score is observed for broilers raised on corn stalks chips litter in comparison with those raised on rice hulls and chopped palm fiber litters, while birds raised on wood sawdust, wheat straw and palm spines chips litters had intermediate values of leg problems.

Birds with leg problems or disorders (foot sores and hock burns) spend more time sitting and, if the litter is wet and dirty with faeces, thes results in burns and sores. Foot and hock burns in turn reduce walking activity because they 
make walking painful. The ability of the bedding to absorb and quickly release moisture and ammonia may be the most important characteristics (Farghly et al. 2015 \& 2020)). Several studies suggested a strong association between "poor" litter quality and foot pad dermatitis (Bilgili $\boldsymbol{e t}$ al., 2009). Petek et al. (2014) indicated that the litter type had significant effect on length of foot pad lesions of the birds litter moisture. The present results are in acordance with those obtained by Davis $\boldsymbol{e t}$ al. (2010) Farghly (2012) and Farghly $e t$ al. (2015) who found that litter type had significant effect on hock burn scores, foot pad dermatitis and walking ability. Bilgili et al. (2009) claimed that incidence of footpad dermatitis paralleled high litter moisture and caking scores. Similar results for breast bristers score were observed by Farghly (2012). However, Yildiz et al. (2014) indicated that the litter material had insignificant effect on feathering score.

\subsection{Economic efficiency:}

The results presented in Table (7), showed that, birds raised on corn stalks chips, palm spines chips and wood sawdust litters had higher economic efficiency than those of birds raised on rice hulls or chopped palm fiber litter, since, the values of relative economic efficiency were 105.4, 105.4 and 103.07 for corn stalks chips, palm spines chips and wood sawdust litters, respectively. Management strategies should focus on what is the best for poultry welfare and growth performance (Mohammed et al., 2019). Amer et al., (2015) and Farghly (2017) reported that litter type had significant effect on economic efficiency.

In conclusion, depends on the economic efficiency and availability palm spines chips litter can be used as litter material instead of wood sawdust and wheat straw. In conclusion, corn stalks chips and palm spines chips can potentially be used as alternative litter materials in New Valley for growing broilers.

Table (1): Means \pm SE of body weight (g) as affected by different litter types.

\begin{tabular}{|c|c|c|c|c|c|c|c|}
\hline \multirow{2}{*}{$\begin{array}{c}\text { Age (wks) } \\
\text { Litter materials }\end{array}$} & \multicolumn{7}{|c|}{ Body weight (g) } \\
\hline & 1 day & 1 wk & $2 \mathrm{wk}$ & 3 wk & $4 \mathrm{wk}$ & 5 wk & $6 \mathbf{w k}$ \\
\hline Wheat straw & 41.9 & 160.4 & 440.6 & 891.2 & 1385.3 & 1792.2 & $2143.9^{\mathrm{a}}$ \\
\hline Wood sawdust & 42.2 & 159.9 & 459.8 & 900.7 & 1382.8 & 1802.6 & $2125.6^{\mathrm{ab}}$ \\
\hline Rice hulls & 40.9 & 154.7 & 430.6 & 878.9 & 1340.7 & 1762.3 & $1921.3^{\mathrm{b}}$ \\
\hline Corn stalks chips & 42.1 & 166.9 & 443.1 & 892.3 & 1401.3 & 1798.2 & $2140.2^{\mathrm{a}}$ \\
\hline Chopped palm fiber & 41.8 & 168.8 & 420.4 & 883.6 & 1372.2 & 1757.1 & $1928.1^{\mathrm{b}}$ \\
\hline Palm spines chips & 42.3 & 158.5 & 448.9 & 906.4 & 1400.4 & 1805.3 & $2139.3^{a}$ \\
\hline SEM & 1.11 & 9.32 & 19.65 & 29.79 & 33.63 & 41.51 & 44.15 \\
\hline$P$ value & 0.6224 & 0.3279 & 0.7226 & 0.9842 & 0.5851 & 0.1965 & 0.0256 \\
\hline
\end{tabular}

Table (2): Means $\pm \mathrm{SE}$ of body weight gain as affected by different litter types.

\begin{tabular}{lccccccc}
\hline \multirow{2}{*}{ Litter me (wks) } & \multicolumn{7}{c}{ Body weight gain (g/bird/day) } \\
\cline { 2 - 8 } & $\mathbf{0 - 1}$ & $\mathbf{1 - 2}$ & $\mathbf{2 - 3}$ & $\mathbf{3 - 4}$ & $\mathbf{4 - 5}$ & $\mathbf{5 - 6}$ & Mean \\
\hline Wheat straw & 16.93 & 40.03 & 64.37 & 70.59 & $58.13^{\mathrm{ab}}$ & $50.24^{\mathrm{a}}$ & $50.05^{\mathrm{a}}$ \\
Wood sawdust & 16.81 & 42.84 & 62.99 & 68.87 & $59.97^{\mathrm{a}}$ & $46.14^{\mathrm{ab}}$ & $49.60^{\mathrm{a}}$ \\
Rice hulls & 16.26 & 39.41 & 64.04 & 65.97 & $60.23^{\mathrm{a}}$ & $22.71^{\mathrm{c}}$ & $44.77^{\mathrm{b}}$ \\
Corn stalks chips $_{\text {Chopped palm fiber }}$ & 17.83 & 39.46 & 64.17 & 72.71 & $56.70^{\mathrm{ab}}$ & $48.86^{\mathrm{a}}$ & $49.95^{\mathrm{a}}$ \\
Palm spines chips & 18.14 & 35.94 & 66.17 & 69.80 & $54.99^{\mathrm{b}}$ & $24.43^{\mathrm{bc}}$ & $44.91^{\mathrm{b}}$ \\
\hline \multicolumn{1}{c}{ SEM } & 16.60 & 41.49 & 65.36 & 70.57 & $57.84^{\mathrm{ab}}$ & $47.71^{\mathrm{a}}$ & $49.93^{\mathrm{a}}$ \\
\hline \multicolumn{1}{c}{ P value } & 2.56 & 3.82 & 4.95 & 5.65 & 6.11 & 5.22 & 4.24 \\
\hline
\end{tabular}

a-----c Means within columns followed by different superscripts are significantly different $(\mathrm{P} \leq 0.05)$. 
Table (3): Means $\pm \mathrm{SE}$ of feed consumption as affected by different litter types.

\begin{tabular}{lccccccc}
\hline \multirow{2}{*}{ Age (wks) } & \multicolumn{7}{c}{ Feed consumption (g/bird/day) } \\
\cline { 2 - 8 } Litter materials & $\mathbf{0 - 1}$ & $\mathbf{1 - 2}$ & $\mathbf{2 - 3}$ & $\mathbf{3 - 4}$ & $\mathbf{4 - 5}$ & $\mathbf{5 - 6}$ & Mean \\
\hline Wheat straw & 28.86 & 60.24 & 91.04 & 110.22 & 121.63 & $129.16^{\mathrm{a}}$ & 90.19 \\
Wood sawdust & 27.91 & 58.43 & 89.22 & 108.81 & 119.81 & $124.24^{\mathrm{b}}$ & 88.07 \\
Rice hulls & 30.18 & 61.42 & 90.68 & 112.32 & 120.12 & $126.53^{\text {ab }}$ & 90.21 \\
Corn stalks chips & 27.22 & 57.61 & 87.22 & 106.91 & 124.22 & $123.18^{\mathrm{b}}$ & 87.73 \\
Chopped palm fiber & 29.86 & 59.25 & 88.95 & 112.11 & 122.46 & $130.06^{\mathrm{a}}$ & 90.45 \\
Palm spines chips & 26.91 & 58.12 & 86.41 & 107.54 & 118.25 & $124.21^{\mathrm{b}}$ & 86.91 \\
\hline \multicolumn{1}{c}{ SEM } & 2.15 & 2.62 & 3.98 & 4.15 & 5.86 & 5.92 & 4.85 \\
\multicolumn{1}{c}{ P value } & 0.8139 & 0.6521 & 0.4589 & 0.8262 & 0.1265 & 0.0282 & 0.26543 \\
\hline \multicolumn{2}{c}{ a---b Means within row followed by different superscripts are significantly different $(\mathrm{P} \leq 0.05)}$.
\end{tabular}

Table (4): Means $\pm \mathrm{SE}$ of feed conversion ratio as affected by different litter types.

\begin{tabular}{lccccccc}
\hline \multirow{2}{*}{ Age (wks) } & \multicolumn{7}{c}{ Feed conversion (g feed/g gain) } \\
\cline { 2 - 8 } Litter materials & $\mathbf{0 - 1}$ & $\mathbf{1 - 2}$ & $\mathbf{2 - 3}$ & $\mathbf{3 - 4}$ & $\mathbf{4 - 5}$ & $\mathbf{5 - 6}$ & Mean \\
\hline Wheat straw & 1.70 & 1.50 & 1.41 & 1.56 & 2.09 & $2.57^{\mathrm{c}}$ & $1.81^{\mathrm{b}}$ \\
Wood sawdust & 1.66 & 1.36 & 1.42 & 1.58 & 2.00 & $2.69^{\mathrm{bc}}$ & $1.79^{\mathrm{b}}$ \\
Rice hulls & 1.86 & 1.56 & 1.42 & 1.70 & 1.99 & $5.56^{\mathrm{a}}$ & $2.35^{\mathrm{a}}$ \\
Corn stalks chips & 1.53 & 1.46 & 1.36 & 1.47 & 2.19 & $2.52^{\mathrm{c}}$ & $1.75^{\mathrm{b}}$ \\
Chopped palm fiber & 1.65 & 1.65 & 1.34 & 1.61 & 2.23 & $5.32^{\mathrm{ab}}$ & $2.30^{\mathrm{a}}$ \\
Palm spines chips & 1.62 & 1.40 & 1.32 & 1.52 & 2.04 & $2.60^{\mathrm{b}}$ & $1.75^{\mathrm{b}}$ \\
\hline \multicolumn{1}{c}{ SEM } & 0.08 & 0.11 & 0.10 & 0.09 & 0.12 & 0.07 & 0.06 \\
\multicolumn{1}{c}{ P value } & 0.1562 & 0.5924 & 0.1562 & 0.6552 & 0.4938 & 0.0132 & 0.0249 \\
\hline
\end{tabular}

a---c Means within row followed by different superscripts are significantly different $(\mathrm{P} \leq 0.05)$.

Table (5): Means $\pm \mathrm{SE}$ of carcass traits as affected by different litter types.

\begin{tabular}{|c|c|c|c|c|c|c|}
\hline \multirow{2}{*}{ Litter materiats } & \multicolumn{3}{|c|}{ Carcass traits, $\%$} & \multicolumn{3}{|c|}{ Immune organs, \% } \\
\hline & Dressing & Giblets & Abd. fat & Spleen & Bursa & Thymus \\
\hline Wheat straw & 75.12 & 5.21 & $2.20^{\mathrm{a}}$ & $0.246^{\mathrm{ab}}$ & $0.486^{\mathrm{a}}$ & 0.213 \\
\hline Wood sawdust & 74.90 & 5.11 & $1.31^{\mathrm{b}}$ & $0.284^{\mathrm{a}}$ & $0.478^{\mathrm{a}}$ & 0.202 \\
\hline Rice hulls & 74.48 & 4.96 & $1.87^{\mathrm{ab}}$ & $0.202^{\mathrm{b}}$ & $0.365^{b}$ & 0.185 \\
\hline Corn stalks chips & 75.00 & 5.15 & $1.30^{\mathrm{b}}$ & $0.242^{\mathrm{ab}}$ & $0.434^{\mathrm{ab}}$ & 0.204 \\
\hline Chopped palm fiber & 74.39 & 5.02 & $1.24^{\mathrm{b}}$ & $0.279^{\mathrm{a}}$ & $0.352^{b}$ & 0.196 \\
\hline Palm spines chips & 75.06 & 5.16 & $1.76^{\mathrm{ab}}$ & $0.241^{\mathrm{ab}}$ & $0.423^{\mathrm{ab}}$ & 0.202 \\
\hline SEM & 4.61 & 0.10 & 0.46 & 0.03 & 0.06 & 0.05 \\
\hline P value & 0.4975 & 0.6132 & 0.0261 & 0.0352 & 0.0185 & 0.6241 \\
\hline
\end{tabular}

a---b Means within columns followed by different superscripts are significantly different $(\mathrm{P} \leq 0.05)$.

Table (6). Means \pm SE of body measurements and health status as affected by different litter types.

\begin{tabular}{|c|c|c|c|c|c|}
\hline \multirow{2}{*}{ Treatments } & \multicolumn{3}{|c|}{ Body measurements (cm) } & \multicolumn{2}{|c|}{ Health status } \\
\hline & Body depth & Keel bone & Shank & Breast blisters & Leg problems \\
\hline Wheat straw & 15.88 & $12.92^{\mathrm{ab}}$ & 6.08 & 1.60 & $2.00^{\mathrm{ab}}$ \\
\hline Wood sawdust & 15.96 & $13.80^{\mathrm{a}}$ & 6.10 & 2.00 & $1.80^{\mathrm{ab}}$ \\
\hline Rice hulls & 15.52 & $13.14^{\mathrm{ab}}$ & 5.86 & 2.20 & $2.40^{\mathrm{a}}$ \\
\hline Corn stalks chips & 16.08 & $13.82^{\mathrm{a}}$ & 6.22 & 1.60 & $1.20^{\mathrm{b}}$ \\
\hline Chopped palm fiber & 15.64 & $12.60^{\mathrm{b}}$ & 5.94 & 2.00 & $2.40^{\mathrm{a}}$ \\
\hline Palm spines chips & 16.12 & $13.70^{\mathrm{a}}$ & 6.12 & 1.80 & $1.40^{\mathrm{b}}$ \\
\hline SEM & 1.86 & 1.21 & 0.52 & 0.59 & 0.31 \\
\hline P value & 0.7543 & 0.0242 & 0.1562 & 0.8712 & 0.0412 \\
\hline
\end{tabular}


Table (7). Economical efficiency of broilers as affected by different litter types.

\begin{tabular}{|c|c|c|c|c|c|c|}
\hline \multirow{2}{*}{ Items } & \multicolumn{6}{|c|}{ Treatments } \\
\hline & $\mathbf{C}$ & T1 & $\mathbf{T} 2$ & T3 & $\mathbf{T 4}$ & T5 \\
\hline Litter costs/bird (L.E) & 0.40 & 0.22 & 0.15 & 0.06 & 0.12 & 0.06 \\
\hline Total costs/ bird/L.F Feed costs (L.E/bird) & 25.00 & 24.41 & 25.01 & 24.32 & 25.07 & 24.09 \\
\hline Total costs/ bird/L.E & 25.40 & 24.63 & 25.16 & 24.38 & 25.19 & 24.69 \\
\hline Selling price of live bird at 6 weeks of age (L.E) & 62.17 & 61.64 & 55.71 & 62.07 & 55.92 & 62.04 \\
\hline Net revenue/ bird/L.E (without *constant costs $=25 \%$ ) & 36.8 & 37.0 & 30.6 & 37.7 & 30.7 & 37.4 \\
\hline Economical efficiency/bird (EE) & 1.47 & 1.52 & 1.22 & 1.55 & 1.23 & 1.55 \\
\hline Relative economical efficiency/bird (REE) & 100.0 & 103.07 & 83.09 & 105.4 & 83.31 & 105.40 \\
\hline
\end{tabular}

\section{References}

Amer F. M., F. N.Soliman, M. Bahie El-Deen and Azza El-Sebai 2015. Effect of diet forms and litter types on the productive traits of broiler (Sasso). Egypt. Poult. Sci. Vol (35) (III): 719-734.

Amer M.M. 2020. Review: Footpad dermatitis (FPD) in chickens. Korean Journal of Food \& Health Convergence 6(4), pp 11-16.

Atencio J. L., J. A. Fernández, A. G. Gernat and J. G. Murillo 2010. Effect of pine wood shavings, rice hulls and river bed sand on broiler productivity when used as a litter sources. Int. J. Poult. Sci. 9:240-243.

Avila V. S., U. Oliveira, E. A. P. Figueiredo, C. A. F. Costa, V. M. N. Abreu and P. S. Rosa 2008. Avaliação de materiais alternativos em substituição à maravalha como cama de aviário. Braz. J. Anim. Sci. 37:273-277.

Balaban G. G. and T. Ç. Rathert 2020 . Applicability of Cotton Gin Waste as Litter Material in Broiler Production. Turkish Journal of Agricultural, 7(2): 342-348.

Bilgili S.F., J.B. Hess, J.P. Blake, K.S. Macklin, B. Saenmahayak and J.L. Sibley 2009. Influence of bedding material on footpad dermatitis in broiler chickens. J. Appl. Poult. Res. 18, 583589.

Davis J. D., J. L. Purswell, E. P. Columbus and A. S. Kiess 2010. Evaluation of chopped switch grass as a litter material. Int. J. of Poult. Sci., 9: 39-42.
Demirulus, H. 2006. The effect of bedding type and bedding thickness on broiler carcass traits. Int. J. Poult. Sci. 5: 670672.

Dhaliwal A.P.S., B. S. Dhillon and J.S. Brar 2018. Evaluation of Different Litter Materials for Broiler Production. International Journal of Current Microbiology and Applied Sciences, 7(12): 1041-1045.

Duncan, D.B. 1955. Multiple range and multiple $\mathrm{F}$ tests. Biometrics Longman, New York, NY, USA.

Farghly M. F., A., M. I. El-Kelawy, A. Y. Kassab and A. M. Hashem 2020. Use of some available plant residues in new valley as alternative litter materials for managing broiler chickens. $5^{\text {th }}$ International Conference on Biotechnology Applications in Agriculture, April 8-11, 2020, Moshtohor and Hurghada, EGYPT.

Farghly M.F.A., Kh.M. Mahrose, R.G. Cooper, Kh.A. Metwally, M.Sh. Abougabal and I.T. El-Ratel 2021. Use of available crop by-products as alternative bedding materials for rearing broilers. Animal: An International Journal of Animal Bioscience, Under publish.

Farghly M.F. A. 2012. Evaluation of clover and corn stalks straw as alternative bedding materials to wheat straw for raising local turkey. Egypt. J. Anim. Prod. 49:161-172.

Farghly, M. F. A., (2017). Using different cage floor and litter types for raising Japanese quail during summer season. The 16th Scientific Conference of Animal 
Nutrition, 28 November to 1 December 2017, Luxor, Egypt (Abstract).

Farghly M.F. A., M. El-Sagheer and H.Y. ElHammady 2015. Impact of different bedding combinations on Japanese quail growth performance and indoor air condition. Egypt. J. Anim. Prod. 52:97103

Farghly M.F.A., Kh. M. Mahrose, R.G. Cooper, Z. Ullah, Z. Rehman and C. Ding 2018. Sustainable floor type for managing turkey production in a hot climate. Poult. Sci., 97: 3884-3890.

Grimes J.L., T.A. Carter and J.L. Godwin 2006. Use of a bedding material made from cotton waste, gypsum, and old newsprint for rearing broiler chickens. Poult. Sci. 85:563-568.

Huang Y., J.S. Yoo, H.J. Kim, Y. Wang, Y.J. Chen, J.H. Cho and I.H. Kim 2009. Effect of bedding types and different nutrient densities on growth performance, visceral organ weight, and blood characteristics in broiler chickens. J. App. Poult. Res. 18:1-7.

Kuleile N., I.Metsing, C.Tjala and T. Jobo 2019. The effects of different litter material on broiler performance and feet health. Online J. Anim. Feed Res., 9(5): 206-211.

Lonkar D., S.Ranade, R.Kulkarni, B.Pathak, D.Yenge and G. Daware 2018. Effect of organic acid treated corn cob bedding material on broiler performance, hock burn incidence and litter quality. Int. J. of Sci., Environ. and Tech., 7(2):397 409.

Mohammed H. H., Asmaa I. Abdelaty, AlSadik Y. Saleem, Mohamed I. Youssef, Shereen and EL. AbdelHamid 2019. Effect of bedding materials on duck's welfare and growth performance. Slov. Vet. Res. 2019; 56 (Suppl 22): 149-56.

Monckton V., N. van Staaveren and A. Harlander-Matauschek 2020. Broiler Chicks' Motivation for Dierent Wood Beddings and Amounts of Soiling. Animals 2020, 10, 1039:1-13.

Munir MT, C. Belloncle, M. Irle and M. Federighi 2019. Wood-based litter in poultry production: a review. Worlds Poult. Sci., J., 75,1-12.

Nawar Z.M., S.A. Ahmed, E. Iraqi, G. Kassem, E.M. Ismail, H.S. Khalefa and S.H. El-Mosalamy, 2019. Impacts of corncobs as an alternative litter material on broiler welfare reared in deep litter system. Inter J Vet Sci, 8(4): 289-293.

Petek, M., H. Üstüner, and D. Yeşilbağ 2014. Effects of stocking density and bedding type on bedding quality and growth performance of broiler chicken. Kafkas Üniversitesi Veteriner Fakultesi Dergisi 20:743-748.

Ramadan S.G.A. and S. Z. El-Khloya 2017. Do alternative litter Materials Affect performance, Welfare and Immune Response of Broiler Chicks? Alex. J. of Vet. Sci., 52(1): 133-141.

SAS 2009. SAS User's Guide, statistics (9.2th ed.) Cary NC: SAS Institute Inc.

Seidavi, A., G. Taherparvar, A. Leila and P.M. Parés-Casanova 2015. Effect of different litters supplemented with chemical agents on broiler carcass components. Journal of Fisheries and Livestock Production 3, 1-4.

Shepherd EM., BD. Fairchild and C.W. Ritz 2017. Alternative bedding materials and litter depth impact litter moisture and footpad dermatitis. Journal of Applied Poultry Research. 26: 518-528.

Škrbić, Z., Z. Pavlovski, M. Lukić, V. Petričević, and D. Milić 2012. The effect of lighting program and type of litter on production and carcass performance of two broiler genotypes. Biotechnology in Animal Husbandry 28, 807-816.

Toghyani, M., A. Gheisar, M. Modaresi, S.A. Tabeidian and M. Toghyani 2010 . Effect of different bedding material on performance and behavior of broiler chickens. Appl. Anim. Behav. Sci. 122:48-52.

Toledo, T.D.S.D., Pich, C.S., Roll, A.A.P., Dai Pra, M.A., Leivas Leite, F., Goncales Xavier, E., and V.F.B. Roll 2019. The effect of litter materials on broiler performance: a systematic 
review and meta-analysis. Br. Poult. Yildiz, A., K. Yildiz, and B. Apaydin 2014. Sci., 60(6): 605-616.

Traldi, C., K.F. Durate, and V.M. Moraes 2007. Avaliação de probióticos na dieta de frangos de corte criados em cama nova ou reutilizada. Rev. Bras. Zootec. 36:660-665.

The effect of Vermiculite as bedding material on some health and stress parameters in broilers. Kafkas Üniversitesi Veteriner Fakultesi Dergisi 20:129-134.

\section{الملخص العبديى}

\section{استخدام بعض مخلفات التخيل المتاحة فى الوادى الجديد كمواد فرشة بديلة لتربية دجاج التسمين}

$$
\begin{aligned}
& \text { محمد فرغلى علم الدين فرغلى1, محمود ابراهيم الكيلاوى2, ايمن يوسف كساب2 و احمد حمح هاشم2 }
\end{aligned}
$$

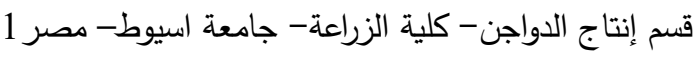

$$
\begin{aligned}
& \text { قسم انتاج الدواجن- كلية الزراعة- جامعة الوادى الجديد- مصر } 2
\end{aligned}
$$

أجريت هذه الدراسة لتقييم تاثير استخدام بعض المتبقيات النباتية كمواد فرشة بديلة متاحة فى الوادى الجديد

على اداء النمو, صفات الذبيحة, الحالة الصحبة و الكفاءة الاقتصادية لدجاج التسمين. 180 كتكوت تسمين عمر يوم (كب500) قسمت إلي ستة مجاميع (3 مكررات لكل مجموعة) طبقا لمعاملات الفرشة. كتاكيت المجموعة الأولى كمجوعة مقارنة

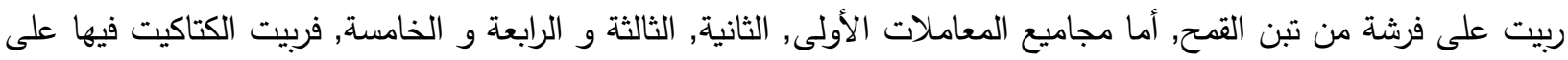
فرشة من نشارة الخشب, قش الارز , تبن سيقان الذرة (البوص), قطع الياف النخيل و قطع زعف النخيل المقصوص علي التوالي. نتائج اداء النمو (وزن الجسم, والزيادة فى وزن الجسم, استهلاك الغذاء و الكفاءة التحولية) فى الفترات النهائية او فى لـى عمر التسويق تعرض اختلافات معنوية بين مجاميع انواع الفرشة. الكتاكيت التى ربيت على فرشة من تبن القدح, تبن سيقان

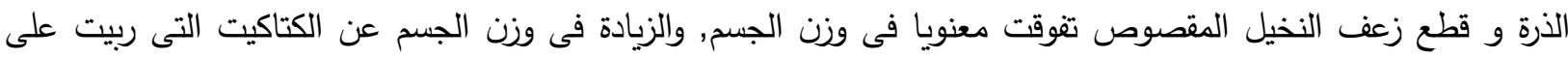

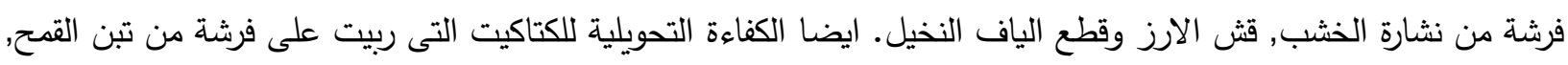

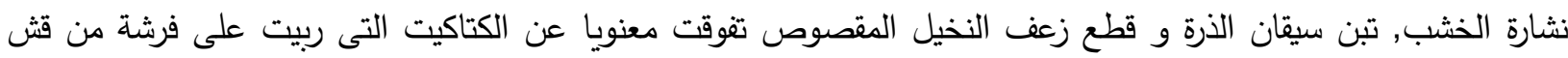

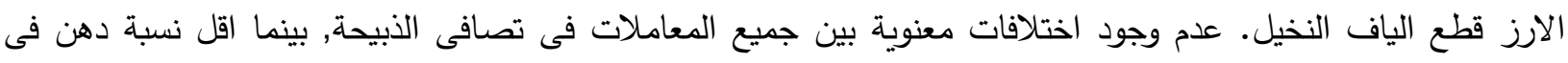
التجويف البطنى لوحظت فى الكتاكيت التى ربيت على فرشة من نشارة الخشب, تبن سيقان الذرة و قطع الياف النخيل. الكتاكيت التى ربيت على فرشة من نشارة الخشب, تبن القهح اعطت زيادة معنوية فى نسبة البرسا عن الكتاكيت التى ربيت على فرشة من قش الارز و قطع الياف النخيل. طول عظمة القص كانت اعلى معنويا للكتاكيت التى ربيت على فرشة من نشارة الخشب, تبن سيقان الذرة و قطع زعف فن النخيل المقصوص مقارنة بالكتاكيت التى ربيت على فرشة من قطع الياف

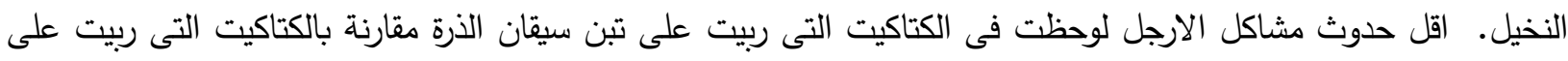

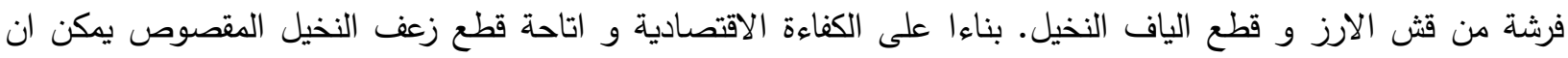
تستخدم كمواد فرشة بدلا من تبن القدح او نشارة الخثب. نخلص من النتائج ان استخدام كلا من سيقان الذرة (البوص) و قطع زعف النخيل المقصوص كمواد فرشة بديلة لرعاية كتاكيت التسمين فى الوادى الجديد. 